\title{
Brazil's response: How did financial regulation and monetary policy influence recovery?
}

\author{
FERNANDO FERRARI FILHO*
}

In the beginning of the international financial crisis, the fact that the international crisis was restricted to the developed countries, and the emerging countries' fiscal and external situation was comfortable, led a number of analysts and policymakers to give credence to the hypothesis of a 'decoupling' of emerging countries; that is, the notion that these economies would be able to sustain their dynamic performance and prove immune to contagion from the crisis. In 2008, moreover, the main concern among central banks, market analysts and multilateral organizations was with the inflationary pressures that emerging countries might suffer as a result of strongly rising food and oil prices.

However, particularly after Lehman Brothers failed in September 2008, economic agents' expectations as to the magnitude of, and developments from, the international financial crisis changed radically. The crisis spread to the whole world economy by a contagion effect, affecting the credit and capital markets, as well as international trade, especially by countries dependent on commodity exports, whose prices fell abruptly. In that context, some emerging countries experienced not just macroeconomic instabilities (in terms of economic activity or price volatility), but also situations of fiscal and external fragility, regardless of whether or not - prior to the crisis - they had displayed what were regarded as sound macroeconomic fundamentals ${ }^{1}$.

The outcome was no different in South America: by the end of 2008, most countries in the region had fallen into recession. In 2009, as shown in Graph 1 (Annex), GDP growth in the region's main emerging countries was negative in

\footnotetext{
* Full Professor of Economics at Federal University of Rio Grande do Sul and CNPq Researcher. E-mail: Ferrari@ufrgs.br.

${ }^{1}$ Remember that in 2008 several rating agencies granted investment grade ranking to emerging and South American countries.
} 
Brazil, Chile and Venezuela, while in Argentina, although GDP posted slight $(0.7 \%)$ positive growth, economic activity slowed considerably as compared with 2008 .

Why did the GDPs of Argentina, Brazil, Chile and Venezuela behave like this in 2009? According to Prates and Cintra (2009), the international financial crisis generated mechanisms by which it was transmitted to these economies, including: (i) withdrawal of portfolio capital (with, incidentally, capital flight eventually affecting stock markets) and foreign direct investment (FDI); (ii) interruption of credit, particularly for foreign trade; (iii) falling commodity prices; (iv) declining exports to developed countries; (v) volatile exchange rates; and (vi) rising levels of profit repatriation by transnational corporations.

Looking at the Brazilian economy, despite the recession in 2009, Brazilian economy recovery strongly in 2010 - according to IBGE the GDP increased $7.5 \%$ - and, as result of, it was one of the less affected economies, showing a remarkable resilience.

This article analyses the policy response of the Monetary Authorities (MA) to the contagion effect of the international financial crisis.

Besides this introduction, the article proceeds as follows: second section presents a brief analysis of the Brazilian economy during the Lula da Silva's second term; third section shows the MA's response to the 2008 international financial crisis; and fourth section 4 concludes.

\section{A BRIEF ANALYSIS OF THE BRAZILIAN ECONOMY FROM 2007 TO 2010}

In 2007, at the start of Lula de Silva's second term, macroeconomic policy - and particularly fiscal policy - underwent a slight change of course. At that time, however much the Brazilian Central Bank (BCB) continued to operate monetary policy in such a way as to meet inflation targets, fiscal policy was orchestrated to support implementation of the Growth Acceleration Program (Programa de Aceleração do Crescimento, PAC), an ambitious program of public and private investments in infrastructure and social projects.

In addition, from 2005 onwards, Brazil — and most other emerging countries - benefited from higher commodity prices, which contributed both to their achieving significant current account surpluses and accumulating international reserves (IMF, 2006) $)^{2}$.

In this scenario and with Brazil growing at around 6\% annually, president Lula da Silva and Brazil's MA at first underestimated the international financial crisis (at the time, president Lula da Silva even remarked that "the financial tsunami would only raise a 'wavelet' in Brazil's economy") to the point that they took no additional, counter-cyclical measures. However, when fourth-quarter 2008 GDP was announced

\footnotetext{
${ }^{2}$ Note that, from 2003 to 2008, Brazil achieved substantial trade balances and a very comfortable foreign trade situation in spite of exchange appreciation, largely as a result of its absorbing sizeable flows of foreign capital attracted by the intensification of financial liberalization during the period of abundant international liquidity.
} 
(down 3.6\% from the third quarter of 2008), that cast doubt on the notion that Brazil was impervious to the effects of the international financial crisis.

Early in 2009, after the initial impact of the crisis had been absorbed, the MA - following the behavior of MA the world over, who actively pursued countercyclical policies to mitigate the effects of the international financial crisis on the real side of the economy - decided to implement counter-cyclical economic measures to reverse the recessive economic trends.

In fiscal policy terms, tax rates (income tax, tax on consumer credit financial operations and tax of industrialized products in the automobile and major household appliance industries) were reduced, public investments were expanded (particularly under the PAC) and a more flexible target fiscal surplus was introduced (from $3.75 \%$ to $2.5 \%$ of GDP).

In its monetary policy, the $\mathrm{BCB}$ injected liquidity into the economy and reactivated the credit market with measures that included changes and reductions in the compulsory deposits required of small and medium banks and large banks and an international export finance credit line set up from funds available from Brazil's international reserves. In addition, however conservative the BCB might be in terms of meeting inflation targets at any cost, in the course of 2009 monetary policy underwent a slow and gradual process in which the annual basic interest rate, Selic (Special System for Settlement and Custody), was reduced.

Accompanying this, other measures played an important part in righting the Brazilian economy: (i) the public banks (Caixa Econômica Federal - CEF, Banco do Brasil - BB - and especially, Banco Nacional de Desenvolvimento Econômico e Social - BNDES -, the stated-owned development bank) operated on the credit market so as to counteract the scarcity of funds caused by the private financial system's preference for liquidity; (ii) lines of external credit were provided and operated by the BCB and the Federal Reserve Bank to meet the private export sector's financing needs; and (iii) there were occasional interventions in the exchange rate market, initially to prevent any devaluation of the real from generating a passthrough effect and thus jeopardizing the inflation targets and later to avert any major exchange rate appreciation.

These measures produced the impact expected, because from the second half of 2009 onwards the Brazilian economy began to show signs of recovery, in turn encouraging expectations among consumers, businesses and the financial system, even to the point of persuading them to take decisions, respectively, to spend (consumption and investment) and borrow.

Thus, note that, on the one hand, Brazil's reaction to the international financial crisis, although tardy, was successful because Brazil did not have a high level of external debt (it is currently a net creditor on the international market), the composition of its public debt had improved ${ }^{3}$, the BCB had built up foreign exchange reserves and the country had diversified both its export portfolio and its array of trade partners. On the other hand, Brazil's economic recovery and restored flows

\footnotetext{
${ }^{3}$ In the late 1990 s and early 2000s, a considerable portion of the public debt was indexed to the exchange rate, while at present nearly all public debt is indexed to the real.
} 
of international capital once again posed longstanding problems associated more with the period of prosperity. These include the tendency for the real to appreciate, affecting industry and the balance of trade ${ }^{4}$, and the BCB's predisposition to want to subordinate fiscal policy to the primacy of monetary policy.

Table 1 shows the performance of some macroeconomic indicators to the Brazilian economy during the Lula da Silva's second term.

Table 1: Brazilian macroeconomic indicators

\begin{tabular}{|l|c|c|c|c|}
\hline \multicolumn{1}{|c|}{ Year } & 2007 & 2008 & 2009 & 2010 \\
\hline Inflation rate, \% & 4.46 & 5.9 & 4.31 & 5.91 \\
\hline GDP rate, \% & 6.1 & 5.2 & -0.6 & $7.5^{*}$ \\
\hline Unemployment rate, \%** & 9.3 & 7.9 & 8.1 & 6.7 \\
\hline Exchange rate, RS/USD*** & 1.92 & 1.83 & 2.00 & 1.76 \\
\hline Interest rate, \%*** & 12.0 & 12.7 & 10.1 & 9.9 \\
\hline Trade balance, USD Billion & 40.0 & 24.7 & 24.6 & 20.3 \\
\hline Current account, USD Billion & 1.5 & -28.3 & -24.3 & -47.5 \\
\hline Foreign reserves, USD Billion & 180.3 & 193.8 & 238.5 & 288.6 \\
\hline Fiscal result/GDP, \% & 3.9 & 4.1 & 2.1 & 2.5 \\
\hline Net public debt/GDP, \% & 43.9 & 38.8 & 43.0 & 41.0 \\
\hline
\end{tabular}

Notes: $\left(^{*}\right)$ Preliminary result according to IBGE; $\left(^{* *}\right)$ Unemployment rate according to the IBGE methodology; $\left(*^{* *}\right)$ Average exchange rate, end of period; and $\left(*^{* * *}\right)$ Selic, annual average.

Source: IBGE (2011), IPEADATA (2011) and BCB (2011).

Based on the Table 1, the macroeconomic indicators show the following:

The average inflation rate from $2007-2010$ was around $5.1 \%$ per year. It is important to stress that in 2008 and 2010 the inflation rates were above the target $(4.5 \%)$ due to commodity price shocks, especially food;

Despite the 2009 recession, the average growth rate of the GDP was $4.5 \%$ per year. During the Lula da Silva's second term, the performance of GDP was determined, basically, for private consumption and government spending, principally those related to the PAC;

In terms of unemployment, the average unemployment rate was $8.0 \%$ per year. Moreover, from 2007 to 2010, the average unemployment rate dropped 2.6\%;

From 2007 to 2010, the average exchange rate, end of period, valued $8.3 \%$. It is important to say that, in part, the exchange rate valued due to the high interest rate - the average Selic in that period was $11.2 \%$ per year;

The combination of exchange rate valuation, world recession in 2009 and the

\footnotetext{
${ }^{4}$ Further details of the tendency for the real to appreciate and the process of "de-industrialization" of the Brazilian economy, a phenomenon known in the economics literature as "Dutch disease", can be found in Bresser-Pereira (2007, Chapter 4).
} 
expansion of domestic demand - due to social programs, PAC and credit facilities — created some difficulties for Brazil's external sector: from 2007 to 2010 the trade balance result declined 49.2, as well as the balance of payments current account changed dramatically — in 2007, there was a balance of payments current account surplus of USD 1.5 billion, while in 2010 it presented a deficit of USD 47.5 billion; moreover, the balance of payment current account accumulated a deficit around USD 100.0 from 2008 to 2010.

To sum up, on the one hand, contrarily to the period 2003-2006 in which the macroeconomic policy was related to the neoliberal tendencies, the second term of the Lula da Silva government the macroeconomic policy moved toward some Keynesian elements of economic policy. In this context, the orthodoxy of the BCB, fiscal policy became more flexible and the GDP growth was induced by fiscal stimulus and government policies. On the other hand, according to Prates and Cintra (2009), the international financial crisis generated mechanisms by which it was transmitted to the Brazilian economy, including: (i) withdrawal of portfolio capital (with, incidentally, capital flight eventually affecting stock markets) and foreign direct investment (FDI); (ii) interruption of credit, particularly for foreign trade; (iii) falling commodity prices; (iv) declining exports to developed countries; (v) volatile exchange rates; and (vi) rising levels of profit repatriation by transnational corporations.

\section{THE POLICY RESPONSES OF THE BRAZILIAN MA TO THE CONTAGION EFFECT OF THE INTERNATIONAL FINANCIAL CRISIS: THE CASE OF BCB ${ }^{5}$}

Due to the first effects of the international financial crisis were felt in the Brazilian financial system, it was the MA that had to respond first. In response to the contagion effect, the Monetary Policy Council (Copom) and the BCB eased monetary policy by lowering the Selic and by increase liquidity in the interbank market. It is worth to mention that the strong contractions of the liquidity on this market after the devaluation of the Brazilian currency (caused by the deepening of the global financial crisis, in September 2008) were related with the losses from exchange derivatives by companies after the real devaluation.

The Selic was lowered by 5 percentage points, from $13.75 \%$ in December 2008 down to $8.75 \%$ in September $2009^{6}$. In December 2009, the real annual rate of Selic was the lowest level in over 10 years: it was equivalent to $4.3 \%$. However, this rate remained far above that of other countries. Moreover, it is worth to men-

\footnotetext{
${ }^{5}$ This section is based on Cunha, Ferrari-Filho and Prates (2011).

${ }^{6}$ In 2009 , five cuts were made: the first one, in the 01/21/2009 Copom meeting, from $13.75 \%$ to $12.75 \%$; the second one, was in the $03 / 11 / 2009$ Copom meeting, to $11.25 \%$; the third one, in the $04 / 29 / 2009$ Copom meeting, to $10.25 \%$; the forth one, was in the $06 / 10 / 2009$ Copom meeting, to $9.25 \%$; and the fifth one, in the $07 / 23 / 2009$ Copom meeting, to $8.75 \%$. Due to inflation effects, the Copom has begun to raise again the basic interest rate on 04/28/2011.
} 
tion that the interest rate reduction in Brazil started with delay. Indeed, in the November 2008 meeting of the Copom, the Committee argued that the threat of inflation caused by the devaluation of the real was high. BCB's rigidity in conducting monetary policy in the last quarter of 2008 strongly contrasted with the actions of its colleagues in the principal advanced ${ }^{7}$ and emerging economies.

Besides the cut on the Selic, a number of measures were adopted to resolve the problem of lack of liquidity in the interbank market and the difficulty of refinancing by smaller banks. For example, the BCB postponed the timetable for implementation of the increase on reserve requirement of leasing companies. According to the schedule established by the BCB in January 2008, the reserve requirement, which was imposed in January 2008, would be increased from $15 \%$ to $20 \%$ in November and to $25 \%$ in January 2009 . With the modifications introduced at $09 / 24 / 2008$, these changes would only take place in January and March 2009, respectively. BCB also established, on 12/10/2008, that leasing companies could deduct from the reserve requirement the amounts referring to foreign currency acquired from the BCB. These currency transactions would be formalized under a resale commitment by the financial institution and a repurchase commitment by the BCB.

It is important to mention that the $\mathrm{BCB}$ uses to impose several compulsory reserve requirements and also additional liability compliance on financial institutions' deposits to control liquidity within the Brazilian financial system. By changing the requirements related to reserve ratios, the BCB influenced the volume of funds available for financial institutions to lend. From September 2008 to December 2008, the $\mathrm{BCB}$ reduced reserve requirements ${ }^{8}$ on cash deposits and time deposits. As a result of, the compulsory reserves were reduced in $\mathrm{R} \$ 99.8$ billion and the liquidity for smaller institutions was increased in $\mathrm{R} \$ 41.8$ billion on the last quarter of 2008 .

To stimulate purchases of credit portfolios from small and medium size banks by the major banks, on $10 / 02 / 2008$, BCB allowed banks to deduct $40 \%$ of the reserve requirements on time deposits to purchases of credit portfolios from financial institutions (with net worth up to $\mathrm{R} \$ 2.5$ billion). On 10/13/2008, BCB once again changed the rules for compulsory collection on term deposits, raising the percentage of the compulsory that banks could deduct for the purchase of other banks' credit portfolios from $40 \%$ to $70 \%$ (there was also a cap of $20 \%$ per transferor financial institution for use of this deduction) and increased the net worth of the seller bank up to R \$ 7 billion. Moreover, on 10/13/2008 and 10/15/2008, BCB extended the range of eligible assets that banks could buy with compulsory resources, authorizing also bond acquisitions from investment fund portfolios, credit rights resulting from leasing, fixed-income instruments issued by private non-fi-

\footnotetext{
${ }^{7}$ Right after the onset of the crisis, the interest rates charged by the major central banks were reduced significantly. At the end of 2009, the base interest rates of the central banks of the United States, United Kingdom and Japan and the European Central Bank stood, respectively, at $0.25 \%, 0.5 \%, 0.1 \%$ and $1.0 \%$ per year.

${ }^{8}$ The BCB began to increase again the reserves requirements on $02 / 26 / 2010$. Until $06 / 30 / 2010$ the process was not yet finished.
} 
nancial entities, assets that make up Receivables Investment Funds (FIDC) or shares in FIDC organized by the Credit Guarantor Fund (FGC).

At the same time, the Government created a new liquidity assistance line. In this way, $\mathrm{BCB}$ was allowed to acquire credit portfolios from financial institutions. The aim was to extended authority for the BCB to assist the Brazilian financial institutions that face cash shortages, mainly small and midsize banks. Access would be given through the rediscount window. Only credits rated AA, A and B (good quality assets) could be accepted by the $\mathrm{BCB}$. The guarantees for these transactions (the ratio between the assets and the rediscount value) ranged from $120 \%$ to $140 \%$, for credits with clients that have transactions involving more than one financial institution or loans secured by the public sector payroll. When dealing with other credits, the BCB demanded guarantees from $150 \%$ to $170 \%$ of the assets underlying the transaction. The financial institution could repurchase its assets by paying the value of said assets plus the variation in the benchmark rate, plus $4 \%$ per year; the asset resale value would be adjusted on a daily basis. Thus, the financial institution accelerated the repurchase of these assets, fully or in part. Moreover, on 10/16/2008, the BCB expanded the range of assets accept as guarantee for these loans, including debentures (fixed income securities issued by companies) rated AA, A and B.

Another measure adopted to solve the lack of liquidity came from financial institutions controlled by the Brazilian government: BB and CEF were authorized to, directly or indirectly, acquire ownership interest on private and public financial institutions in Brazil, including insurance companies, social welfare institutions and capitalization companies, with or without the acquisition of the capital stock control. The Government instituted the Bank Deposit Receipt (RDB) with the special guarantee of the FGC, the national private deposit insurance institution. With this measure, the deposit insurance on time deposits was increased from $\mathrm{R} \$ 60,000.00$ to $\mathrm{R} \$ 20$ million. This measure was adopted because the others ones (mentioned above) were quite innocuous; that is, they did not encourage interbank lending neither the purchase of credit portfolios by major banks. Given the preference for liquidity by private banks and the possibility of the liquid, profitable and very low risk investments in public bonds, the banks simply did not expand interbank credit ${ }^{9}$. In fact, only the stated-owned banks (BB and CEF) acquired a lot of credit portfolios. With the RDB, liquidity in the interbank market began to flow again. Thus, this last measure was, finally, effective.

In addition to the measures of monetary policy, the Brazilian government decided to use the three major federal public banks (BB, CEF and BNDES) to expand credit and to play a countercyclical role in a context of tightening credit conditions by private banks. Besides the two measures mentioned before (authorization for $\mathrm{BB}$ and $\mathrm{CEF}$ to acquire ownership interest on private and public financial institutions in Brazil and the BNDES' capitalization), on 11/6/2008 the Ministry of

\footnotetext{
${ }^{9}$ Although no takeovers took place, significant mergers were announced in the banking sector in the fourth quarter of 2008: one between the private banks Itaú and Unibanco, which became the largest bank in Brazil, and another between BB and Nossa Caixa (State-owned). Furthermore, BB also acquired an ownership interest $(49.9 \%$ ) on Votorantim Bank (privately owned).
} 
Finance announced a series of new initiatives that together provided $\mathrm{R} \$ 19$ billion in credit lines for various sectors, via BNDES and BB in August 2009, and the Government made an additional contribution of R $\$ 500$ million in August 2009 to the endorsement funds of BB and BNDES, which guaranteed loans to small and midsize enterprises. Furthermore, the state-owned banks established also new credit lines to maintain the supply of credit to individuals and companies in a context of high liquidity preference by private banks and, so, to avoid a sharp drop of the economic activity, as well as there was a cut in the Long Term Interest Rate (TJLP), used at the BNDES loans, form $6.25 \%$ down to $6 \%$, the lowest level in history.

Finally, it is important to stress that the adoption of government's banking restructuring programs ${ }^{10}$ during the Real Plan, especially in 1995 and 1996, were fundamental to consolidate and regulate the Brazilian financial system.

\section{CONCLUSION}

As highlighted by Prates and Cintra (2009), in previous crises - more particularly the exchange crises of the 1990s (Mexico, 1994-1995; East Asia, 1997; Russia, 1998; and Brazil, 1998-1999) — most emerging countries took pro-cyclic (restrictive) measures, in line with International Monetary Fund principles and approval, to aim to regain the confidence of the financial markets as a necessary condition for foreign capital to flow back to those emerging economies.

In view of the systemic nature of the present crisis, however, emerging countries' MA decided such policies would be completely ineffective. Rather they would contribute to aggravating the developments from the crisis by setting off a vicious circle of exchange depreciation, credit squeeze, asset deflation, and crises of effective demand and unemployment. In that light, these countries met the contagion effect - as did the developed countries - by putting in place anti-cyclical measures to render their currencies less volatile, prevent balance of payment deterioration, assure liquidity for their domestic financial systems, stabilize prices and bring growth back on track.

In Brazil, the situation was not different. The Government, although tardy, responded to the contagion effect of the systemic international financial crisis with a broad variety of countercyclical economic measures, whose objective was to mitigate this effect both on the Brazilian financial system and on the economic activity. The BCB and the Ministry of Finance spearheaded the crisis response. Beyond the stimulus package, this response also involved important measures of monetary, credit and finance, fiscal, exchange rate and sector policies.

\footnotetext{
${ }^{10}$ At the end of 1995, BCB created the PROER (Program to Support the Restructuring and Strengthening of the National Financial System) to preserve the solvency of the financial system, and in1996 the BCB implemented the PROES (Program of Incentive for the Reduction of the States' Participation in Banking Activities) to aim at restructuring the state public-sector financial system. Moreover, during 1995 and 1996 the BCB introduced some flexibility in the norms related to the entry of foreign banks in Brazil. For more details, see, for instance: Paula, L.F. (2011).
} 
In this way, the $\mathrm{BCB}$ monetary policies and liquidity measures were fundamental to the Brazilian economy recovery. Surprisingly, despite the fact BCB adopts inflation target regime, in which it signals a clear commitment to price stability in a freely floating exchange rate system, the $\mathrm{BCB}$ operated countercyclical economic policies.

To conclude, the BCB response to the international financial crisis seems remember the Keynes (1964)' argument that, due precisely to the relationship between currency and other real or financial assets, grants monetary policy some ability to influence the real variables of monetary economies.

\section{REFERENCES}

BRAZILIAN CENTRAL BANK - BCB (2011). Séries Temporais. http://www.bcb.gov.br, accessed in March.

BRESSER-PEREIRA, L.C. (2007). Macroeconomia da Estagnação: crítica da ortodoxia convencional no Brasil pós-1994. São Paulo, Editora 34.

CUNHA, A.M.; FERRARI-FILHO, F.; PRATES, D.M. (2011). Brazil Responses to the Global Financial Crisis: a well succeed example of Keynesian policies? Mimeo.

INSTITUTO BRASILEIRO DE GEOGRAFIA E ESTATÍSTICA — IBGE (2011). Séries Estatísticas. http://www.ibge.gov.br, accessed in March.

INTERNATIONAL MONETARY FUND - IMF. (2011). Data and Statistics. http://www.imf.org, accessed in March.

IPEADATA (2011). Séries Históricas. http://www.ipeadat.gov.br, accessed in March.

KEYNES, J.M. The General Theory of Employment, Interest and Money. New York: HBJ Book, 1964. PAULA, L.F. (2011). Financial Liberalization and Economic Performance: Brazil at the crossroads. London, Routledge.

PRATES, D.M.; CINTRA, M.A.M. (2009). Os países emergentes diante da crise financeira global. Anais do II Encontro Internacional da Associação Keynesiana Brasileira. Porto Alegre, AKB, CD-ROM.

\section{Graph 1: Gross Domestic Product, \%}

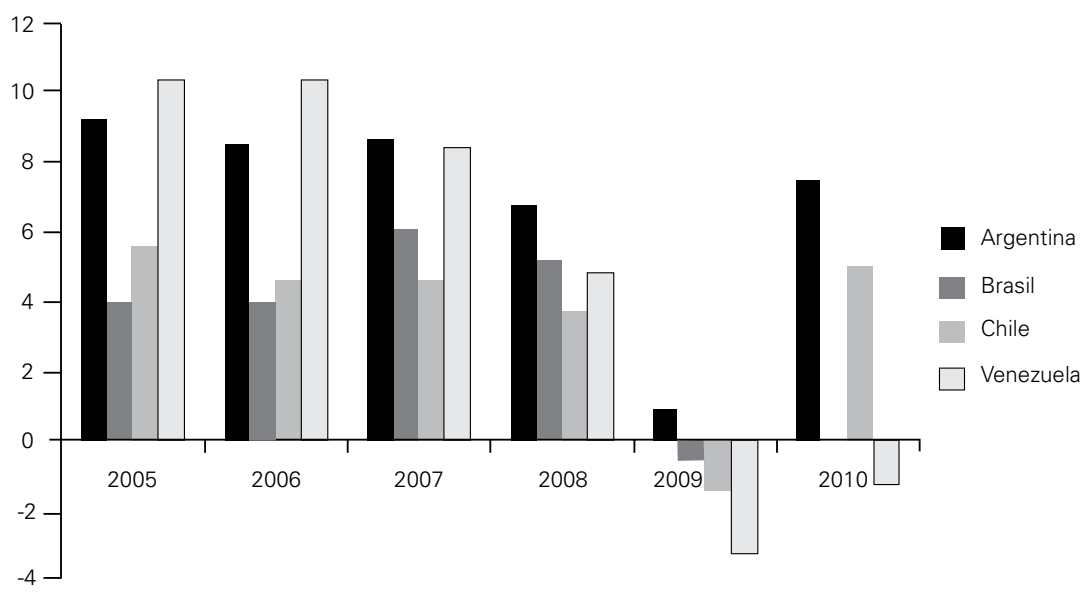

Source: IMF (2011) 